\title{
Use of DAIME for characterisation of activated sludge flocs
}

\author{
Anna Gnida* \\ Silesian University of Technology, Poland \\ Environmental Biotechnology Department \\ ${ }^{*}$ Corresponding author's e-mail: anna.gnida@polsl.pl
}

Keywords: activated sludge, DAIME, flocs characteristics, flocs morphology, image analysis.

\begin{abstract}
Monitoring of activated sludge flocs may provide important information for effective operation and control of wastewater treatment. The research objective is to demonstrate methodology for activated sludge image processing aimed to describe morphological characteristics of activated sludge flocs. The proposed software-based method was presented and verified by analysis of several activated sludge samples. The results show high efficiency of image segmentation and floc recognition of more than $94 \%$ floc components. The analysis of a series of 50 pictures gives rapid and reliable results and can be performed in an automatic or semiautomatic mode. Given inherent heterogeneity of activated sludge flocs, multiple and repeated sample images capture (processing of 50 pictures at a time, repeated at least 4 times ) is recommended.
\end{abstract}

\section{Introduction}

Activated sludge forms a complex floc environment consisting of biotic (viruses, bacteria, archaea, protozoa) and abiotic (extracellular polymers, debris) elements. These components form the structure of the flocs, which reflects the condition of wastewater treatment system and determine settling properties of the activated sludge. Regular monitoring of microscopic parameters of activated sludge flocs may provide important information for dynamic changes in operational parameters of wastewater treatment. Correlations between sludge floc properties and wastewater composition have been found. These included biochemical:chemical oxygen demand ratio (BOD:COD), carbon to nitrogen ratio $(\mathrm{C}: \mathrm{N})$, toxic compounds inhibition, operational conditions (hydraulic and sludge loading rate, recirculation ratio), aeration equipment, substrate uptake rate, oxygen uptake rate, treatment efficiency, excess sludge production, sludge volume index (Liwarska-Bizukojć 2005).

Automated image analysis has become a widely-used tool to obtain rapid, precise and objective data that visually assess floc characteristics without very laborious and time-consuming tests. A variety of software has been used for this purpose, e.g. Visilog by Noesis (Motta et al. 2001, Pandolfi et al. 2007), Matlab (Mesquita et al. 2010, Khan et al. 2015) or NIS Elements AR by Nicon (Liwarska-Bizukojć et al. 2013). Moreover, there are methods that allow for segmentation of an image to show the area of an image covered specifically by flocs, filamentous bacteria or protozoa separately (Mesquita et al. 2010, Liwarska-Bizukojć et al. 2013).

The methods comprise such steps as: sample and microscopic slide preparation, image processing and objects analysis (Liwarska-Bizukojć 2005). The image processing process depends on the chosen method and the purpose of analysis. It may include background correction and transfer of RGB (Red Green Blue) images to grey scale ones, debris rejection, image segmentation and measurement of morphological parameters (Liwarska-Bizukojć et al. 2013).

DAIME (Digital Image Analysis in Microbial Ecology) is a software developed as a tool for image analysis of biological samples and created by Microbial Ecology Department at Vienna University of Technology. It is designed to mostly process fluorescence images and enable image segmentation, microbe abundance determination, molecular probes evaluation, 2D and $3 \mathrm{D}$ visualisation and analysis of co-aggregation. The most effective techniques are those based on fluorescence methods. However, segmentation of bright field microscopy images of activated sludge using edge detection for biomass recognition has proven to provide representative results. DAIME has a user-friendly interface and gives an opportunity to process many images of the same sample concurrently (image series analysis).

The aim of the study is to demonstrate applicability and the efficacy of an image processing method to characterise activated sludge flocs using freely available software DAIME.

\section{Methods}

\section{Biomass sampling}

Activated sludge samples were taken from municipal wastewater treatment plant at random operational days. Due to high suspended solids content in the region of 3-4 g/L the sludge was diluted ten-fold. All the samples of activated sludge were characterised 
by the filaments index of 0 or 1 according to Eikelboom (2000). A volume of $25 \mu \mathrm{L}$ was taken to a microscopic slide and covered with a $24 \times 24 \mathrm{~mm}$ cover slip. Images were taken under direct light using Zeiss Axioscope microscope equipped with AxioCamMR3. Activated sludge images were made with magnification of 50 times and 40-70 images per sample were taken and stored in the TIFF format.

\section{Image analysis}

Image analysis was performed using DAIME, which is freely available at http://dome.csb.univie.ac.at/daime (Daims et al., 2006). The analysis comprised several steps: scaling, segmenting, debris and non-floc objects removal, bordering objects removal and objects measurements. Figure 1 presents schematic representation of the proposed method. Although DAIME has vast functionality and a variety of parameters, the presented method has used such parameters that were found to be optimal and most adequate for floc marking. Figure 1.

Steps 1 to 5 were designed to decontaminate the image from non-floc objects and separate flocs from the background. The micrometer scale of an image depends on microscope magnification and camera settings that were used to acquire the image (Daims et al. 2011) and is determined at the start of the analysis. Setting scaling parameters at a later point of image analysis results in the loss of data. The segmentation process is automatic and is performed for all the images in the imported series. Edge detection (besides threshold detection) was found the most suitable for flocs segmentation. The segmentation process should include dark regions as such parts of the flocs comprise flocs' core and should not be ruled out from the sketch. The removal of debris and non-floc particles can be done manually or automatically depending on sample type and image quality.

DAIME software has built-in segmentation functionality that can be tailored for user's needs. Firstly, the removal of particles from flocs can be done based on selected object size threshold or allowable range. Secondly, it is feasible to automatically classify objects on image series according to desirable parameters that are available within the software settings. The most typical parameters include size, perimeter length, perimeter/area ratio, circularity, minimum and maximum caliper diameter (Feret's value), ratio of the callipers, centroid, number of pixels and their intensity (all the parameters and their calculation methods are presented in user manual (Daims et al. 2011)). The operator may choose the lower and upper limit of the parameter. The software gives also options to use several filters to remove and improve background of the image or enhance objects visualisation but those tools have proven not to be useful in activated sludge bright field microscopy images.

Chosen segmentation parameter had impeded the direct and automatic removal of boundary bisected flocs (flocs touching or crossing the boundary of the image) and needs steps $6-13$ to be performed. This part of analysis is quick and simple due to no need for additional selection parameters such as the debris and non-floc objects rejection. Steps 6-11 aimed to automatically mark only the boundary of bisected flocs. The final step of the bisected flocs removal relies on overlapping of original image series (previously segmented and with floc selection) with the series where only the boundary bisected flocs are selected (step 12-14). The extended object editor function is used to exclude the boundary bisected flocs. Using the congruency threshold (the degree of overlap of the two

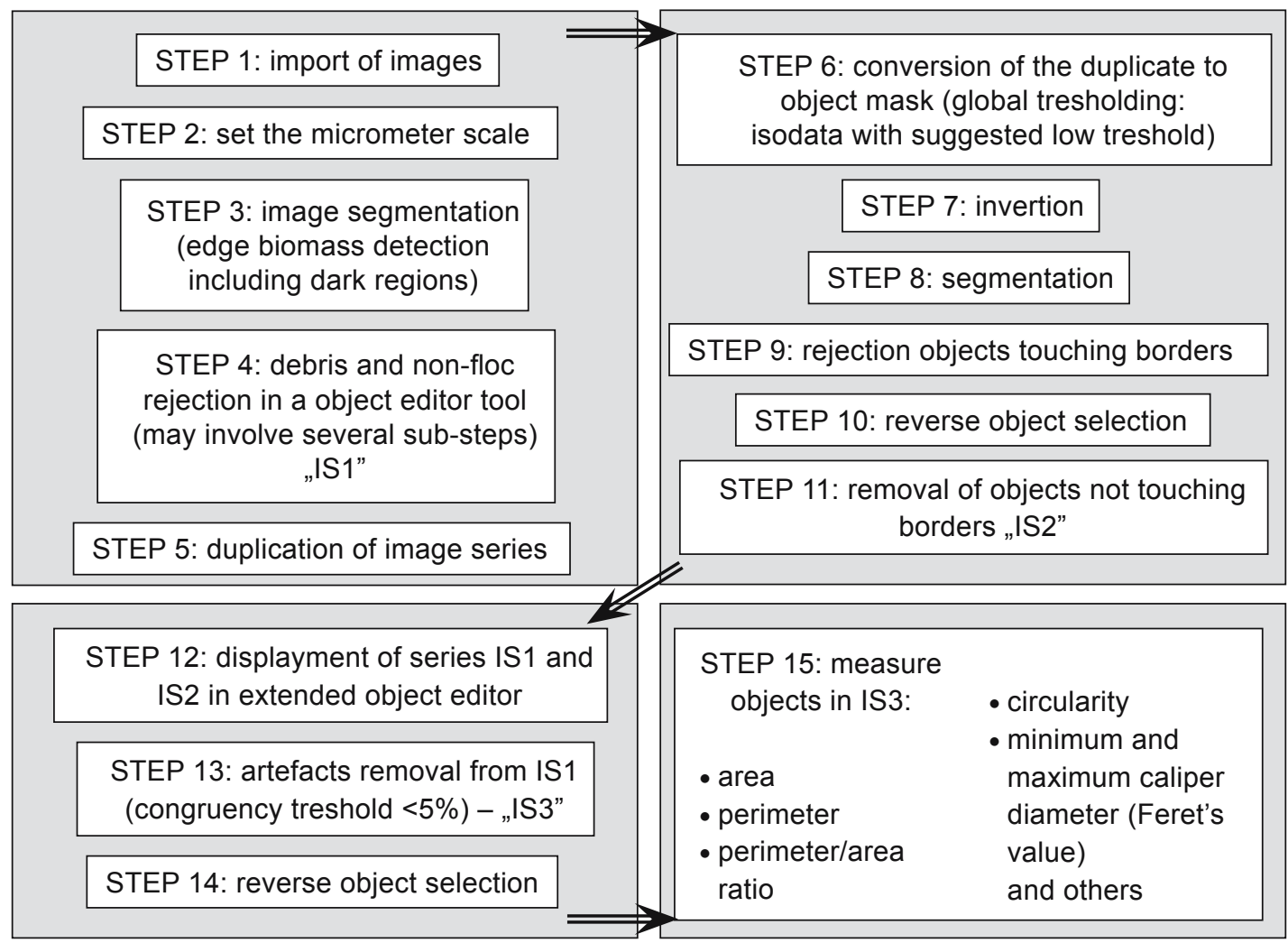

Fig. 1. Schematic representation of the image analysis procedure 
series) of less than 5\% all the non-boundary bisected flocs can be selected (step 13). At step 14 reverse selection is necessary to select and remove boundary bisected flocs. Finally, in step 15 the operator measures all the aforementioned parameters for all images of the analysed series as well as the number of selected and rejected objects of each image. The results can be exported to a preferable file format, including TIFF.
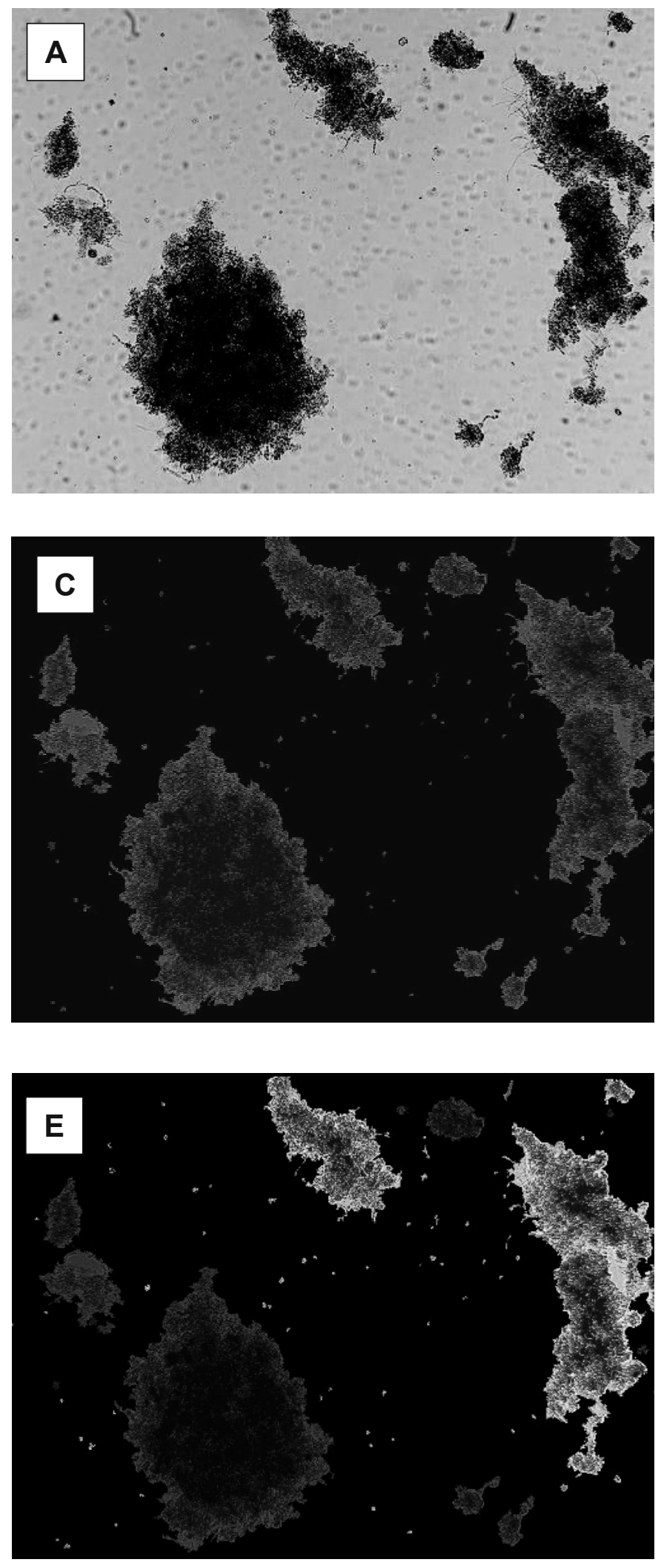

Fig. 2. Image of activated sludge under processing by presented procedure

\section{Results and discussion}

Figure 2 presents an image of activated sludge flocs that was analysed by means of the proposed method.

Figure $2 \mathrm{~A}$ is the original image of activated sludge prior to the processing. A significant amount of debris in the background can be seen. After automatic segmentation (step
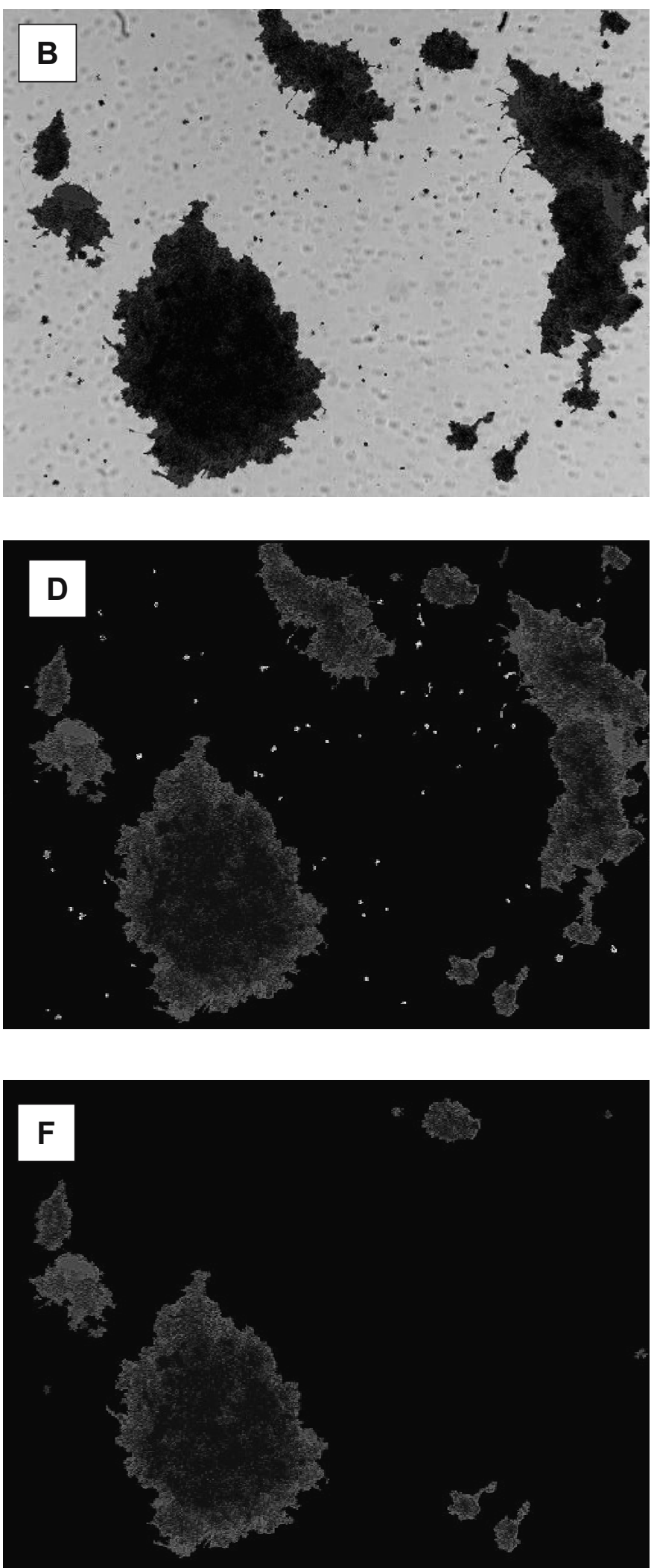
3 of the procedure presented in Figure 2) there are 80 objects selected (Figure 2B). For better visualisation of selected objects a non-object pixels have been removed from the image (Figure 2C). Figure 2D shows two groups of objects - grey objects are selected and white objects have a reject status. Objects highlighted as white are residual debris that can be marked by several ways presented in the previous section. In this example, all the objects that were measured as below the chosen size threshold were rejected (Figure 2D). Steps 6 to 13 of the analysis result in automatic rejection of boundary bisected flocs, which are marked white. In Figure $2 \mathrm{E}$ they are marked white (together with other debris objects). Finally, eleven objects are selected for the measurement of morphological parameters (Figure 2F).

The results showing the accuracy of the segmentation process are presented in Table 1. After segmentation of around 50 images of five different activated sludge samples, the segmentation result was checked and corrected manually by the rejection of non-floc objects (after debris elimination) or additional sectioning of objects that were not accounted for by the automatic segmentation. The effectiveness of the segmentation process has been estimated to exceed $94 \%$ in all five sludge samples, which proves robustness and repeatability of the tested method.

The DAIME software allows for automatic measurement of such floc properties as: surface, area, perimeter, perimeter/ area ratio, circularity, minimum and maximum caliper diameter (Feret's value) and others. In order to determine the number of images to be processed the statistical analysis of the measured flocs features was performed. Median value of a parameter was found to be the most representative to assess the minimum number of images that should be processed (Figure 3 ).

The analyses have shown that the number of images that need to be taken and processed for flocs characterisation should be at least 50 . The number of analysed flocs is also an important parameter that needs to be considered. Here, around 13 objects per image were detected which is in agreement with other researchers who found that for floc analysis at least 150 flocs should be taken and the number of processed images should be between 40 and 70 (Grijspeerdt and Verstraete 1997, Motta et al. 2001, Liwarska-Bizukojć and Bizukojć 2005).

Mesquita et al. (2010) revealed the influence of sample dilution (or suspended solids concentration in activated sludge) on flocs morphology results. If the number of flocs or other objects per microscopic slide is too high, they overlap and can appear as large flocs contrary to real conditions. To select the most appropriate dilution factor, it is recommended to calculate percentage aggregate recognition parameter. This parameter is a ratio of total area of whole flocs on image to total area of flocs including flocs that are partly visible on image (boundary bisected image).

Accurate sample magnification is another crucial parameter for enabling reliable test results (Mesquita et al. 2010). Also in this case, the previously mentioned recognition parameter can be used to make a choice of the magnification level. If the magnification is too high, many of the flocs will be boundary bisected and the recognition parameter will be high. Incorrect magnification can result in the largest agglomerates

Table 1. Effectiveness of segmentation of activated sludge images

\begin{tabular}{|c|c|c|c|c|c|}
\hline $\begin{array}{c}\text { Number } \\
\text { of sample }\end{array}$ & TSS, g/l & $\begin{array}{c}\text { Number } \\
\text { of images }\end{array}$ & $\begin{array}{c}\text { Number of flocs } \\
\text { after autosegmentation }\end{array}$ & $\begin{array}{c}\text { Number of flocs } \\
\text { after correction }\end{array}$ & Effectiveness of segmentation, \% \\
\hline 1 & 5.1 & 50 & 689 & 652 & 94.6 \\
\hline 2 & 2.9 & 50 & 286 & 270 & 94.3 \\
\hline 3 & 2.5 & 45 & 530 & 506 & 95.5 \\
\hline 4 & 3.6 & 50 & 644 & 634 & 98.4 \\
\hline 5 & 2.2 & 50 & 652 & 629 & 96.5 \\
\hline
\end{tabular}

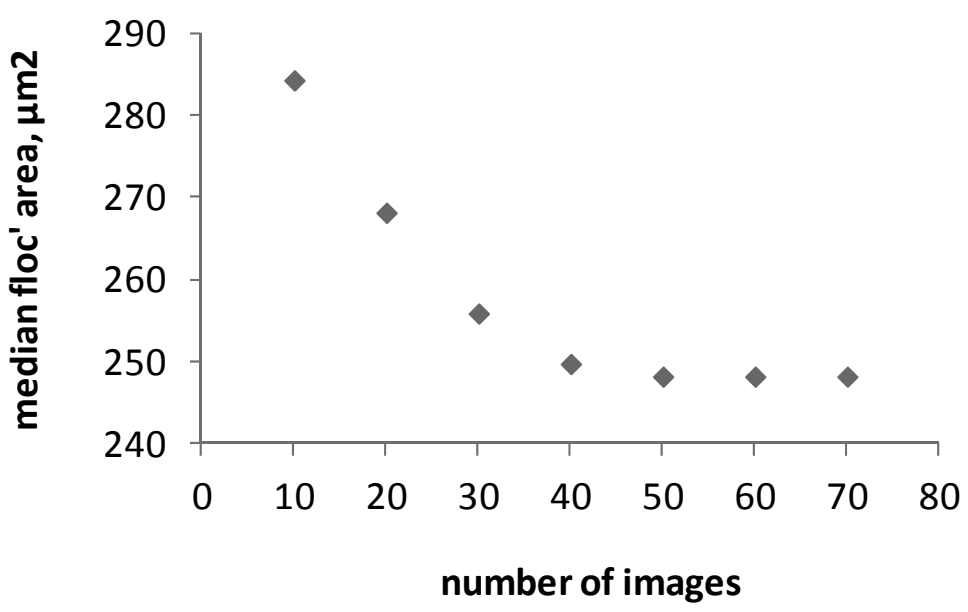

Fig. 3. Median floc area in the function of number of images 
being omitted from the analysis. In the case of activated sludge with large flocs a motorized stage microscope would be very helpful as it allows for images grabbing using the mosaics method (image composed of several images that have a common image edge). It can be also proposed in the case of lower magnification objective not being available. DAIME allows for the processing of such folded images. This solution was also published by Liwarska-Bizukojć (2012).

The results provided in Table 2 show that the number of repetitions performed is a critical parameter for the success of the DAIME method. Table 2 presents coefficient of variation known also as a relative standard deviation that expresses the precision and repeatability of an analysis. It is defined as the ratio of the standard deviation to the mean value and expressed as percentage.

The results in Table 2 show that two test repetitions enhance the standard deviation of the result for objects/flocs larger than median. An addition of single repetition makes the results more equal between repetitions, only the maximal flocs size show high standard deviation results. It has been found that at least 4 test repetitions give comparable and reliable results.

Moreover, the proposed DAIME image analysis method covers the analysis of aggregates and excludes filamentous bacteria. The latter bacteria would be probably partly invisible in the magnification and microscopy technique used in this study. The filamentous bacteria are a nuisance constituent of activated sludge flocs and the filaments to aggregates ratio has been found as important factor for monitoring bulking and sedimentation issues. For this reason, separate analysis of aggregates and filamentous bacteria is recommended (Pandolfi et al. 2007, Liwarska-Bizukojć et al. 2013, Khan et al. 2015). It is important to emphasise that the proposed procedure is suitable for sludges without or with low filaments content. It should also be suitable for flocculation and coagulation research. Separate analysis of filamentous bacteria using DAIME software needs further extensive investigation.

In order to check the applicability of the proposed method to test filamentous bacteria a short experiment has been performed. DAIME analysis was conducted on two samples: (i) healthy activated sludge and (ii) activated sludge treated with a stressing agent for destruction of some of the flocs. Results of that experiment (Figure 4) show that activated sludge treated with the floc-disrupting agent has smaller flocs than untreated sludge. For example, there were approximately. 14\% more flocs of a size lower than $75 \mu \mathrm{m}$ in the treated sludge.

\section{Conclusions}

DAIME software allows for efficient segmentation, image processing and measurement of morphological parameters of activated sludge flocs. The analysis of a series of 50 pictures can be automatic or semiautomatic and gives repeatable results. Due to heterogeneity nature of activated sludge flocs more than 4 images capture repetitions (processing of 50 pictures at a time, repeated at least 4 times) is recommended.

\section{Acknowledgement}

The research was financed by the Polish National Research Centre under the project entitled "Assessment of low vacuum effect on bacteria, activated sludge and wastewater treatment efficiency" (project no 2013/11/D/NZ9/02608). I thank Anna Niemiec who has contributed to this study by sample and microscopic images preparation.

Table 2. Variation coefficient of flocs area calculated from 50 images of a random chosen activated sludge sample

\begin{tabular}{|c|c|c|c|c|}
\hline & 2 repetitions & 3 repetitions & 4 repetitions & 6 repetitions \\
\hline minimum & 1 & 1 & 0 & 0 \\
\hline quartile 1 & 2 & 5 & 5 & 5 \\
\hline median & 10 & 5 & 5 & 5 \\
\hline quartile 3 & 11 & 10 & 12 & 11 \\
\hline maximum & 1535 & 427 & 65 & 65 \\
\hline
\end{tabular}

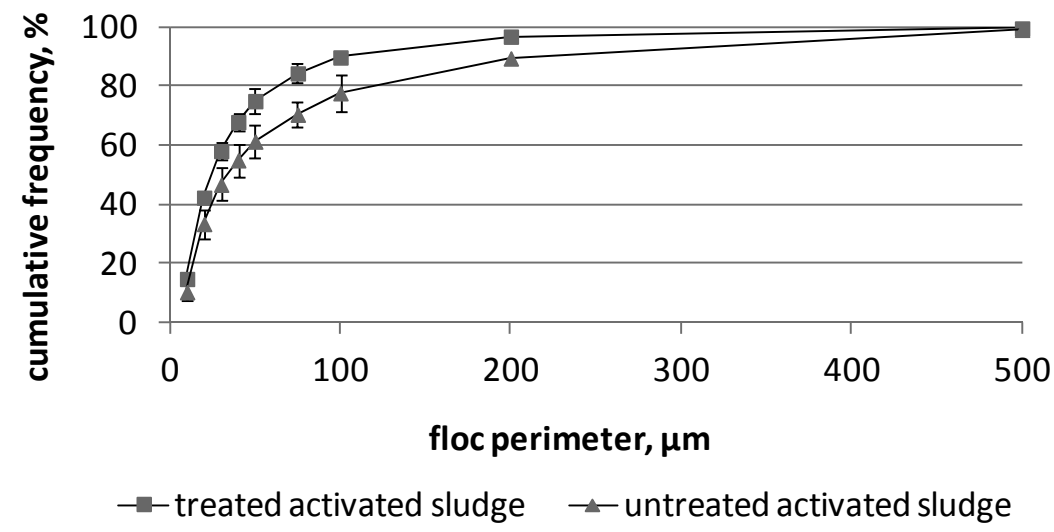

Fig. 4. Percentage freguency of floc size expressed by floc perimeter 


\section{References}

Daims, H., Lucker, S. \& Wagner, M. (2006). Daime, a novel image analysis program for microbial ecology and biofilm research, Environmental Microbiology, 8, 2, pp. 200-213.

Daims, H. et al. (2011). DAIME - user manual, DOME, Vienna, Austria

Eikelboom, D. (2000). Process control of activated sludge plants by microscopic investigation, IWA Publishing, UK 2000.

Grijspeerdt, K. \& Verstraete, W. (1997). Image analysis to estimate the settleability and concentration of activated sludge, Water Research, 31, 5, pp. 1126-1134.

Liwarska-Bizukojć, E. (2005). Application of image analysis techniques in activated sludge wastewater treatment processes, Biotechnology Letters, 27, 19, pp. 1427-1433.

Liwarska-Bizukojć, E. \& Bizukojć, M. (2013). New automated procedure to determine the contribution of filamentous bacteria in activated sludge flocs, Journal of Civil Engineering, Environment and Architecture, 60, 3, pp. 59-68. (in Polish)
Liwarska-Bizukojć, E. (2012). Role of digital image analysis in activated sludge monitoring in wastewater treatment plants, Inżynieria i Aparatura Chemiczna, 51, 4, pp. 151-153. (in Polish)

Khan, M.B., Nisar, H., Ng, C.A. \& Lo, P.K. (2015). Illumination compensated segmentation of microscopic images of activated sludge flocs, International Conference on Digital Image Computing: Techniques and Applications (DICTA), Adelaide, SA, pp. 1-5.

Mesquita, D.P., Dias, O., Elias, R.A.V., Amaral, A.L. \& Ferreira, E.C. (2010). Dilution and magnification effects on image analysis applications in activated sludge characterization, Microscopy and Microanalysis, 16, 5, pp. 561-568.

Motta, M., Pons, M., Roche, N. \& Vivier, H. (2001). Characterisation of activated sludge by automated image analysis, Biochemical Engineering Journal,9, 3, pp. 165-173.

Pandolfi, D., Pons, M.N. \& da Motta, M. (2007). Characterization of PHB storage in activated sludge extended filamentous bacteria by automated colour image analysis, Biotechnology Letters, 29 , 8, pp. 1263-1269.

\section{Wykorzystanie programu DAIME do opisu kłaczków osadu czynnego}

Streszczenie: Analiza mikroskopowa osadu czynnego może dostarczyć ważnych informacji dla prawidłowego funkcjonowania i kontroli oczyszczania ścieków. Celem badań jest przedstawienie procedury przetwarzania i analizy obrazów osadu czynnego zmierzające do opisania cech morfologicznych kłaczków. Program DAIME użyto do oceny parametrów kłaczków osadu czynnego. Proponowana procedura wykorzystania tego programu została przedstawiona i zweryfikowana poprzez analizę kilku próbek osadu czynnego w maksymalnie 6 powtórzeniach. Każda seria składała się z 10 do 70 obrazów. Analizowane kłaczki zliczono a wyniki zmierzonych parametrów morfologicznych kłaczków poddano analizie statystycznej. Wyniki przetwarzania obrazu zostały pokazane jako prezentacja obrazów z kolejnych kroków analizy. Wyniki pomiarów parametrów morfologicznych wskazują na wysoką efektywność segmentacji obrazu i rozpoznawania kłaczków wynoszącą ponad 94\%. Wielkość kłaczków została wybrana spośród dostępnych parametrów, aby pokazać ile obrazów należy poddać obróbce i w ilu powtórzeniach wykonać analizę, aby uzyskać wiarygodne wyniki analizy. Program DAIME umożliwia dobrą segmentację i nadaje się do przetwarzania i pomiar parametrów morfologicznych kłaczków osadu czynnego. Analiza serii składającej się z 50 zdjęć jest szybka, może być automatyczny lub półautomatyczny, a daje wiarygodne wyniki. W świetle heterogeniczności osadu czynnego zalecane jest wykonanie ponad 4 powtórzeń (czterokrotne przetwarzanie co najmniej 50 zdjęć). 